\title{
Perbedaan Aktivitas Fisik Remaja Laki-Laki dan Perempuan yang Mengikuti Car Free Day Dago Kota Bandung
}

\author{
Iik Supriyatna ${ }^{1}$, Mustika Fitri ${ }^{1}$, Jajat ${ }^{1,2}$ \\ ${ }^{1}$ Program Studi Ilmu keolahragaan, Departemen Pendidikan Kesehatan dan Rekreasi, Fakultas \\ Pendidikan Olahraga dan Kesehatan, Universitas Pendidikan Indonesia, Indonesia \\ ${ }^{2}$ Pendidikan Jasmani Kesehatan dan Rekreasi, Universitas Galuh Ciamis
}

\begin{tabular}{l}
\hline Info Artikel \\
\hline Sejarah Artikel: \\
Diterima: Oktober-2018 \\
Disetujui: Oktober-2018 \\
Dipublikasikan : Oktober-2018 \\
\hline Kata Kunci: \\
Aktivitas fisik, remaja laki-laki \\
dan perempuan, Car free day, \\
aktivitas olahraga \\
\hline
\end{tabular}

\begin{abstract}
Abstrak
Tujuan penelitian ini yaitu untuk mengetahui perbedaan aktivitas fisik remaja laki-laki dan perempuan yang mengikuti car free day Dago Kota Bandung. Penelitian ini merepakan penelitian deskriptif dengan pendekatan kuantitatif. Objek dari penelitian ini adalah remaja yang mengikuti car free day Dago Kota Bandung dengan jumlah sampel 100 orang remaja yang di kelompokan menjadi dua yaitu 50 remaja laki-laki dan 50 remaja perempuan. Instrumen pada penelitian ini berupa kuesioner yaitu Global Physical Activity Questionnaire untuk mengukur tingkat aktivitas fisik dengan reliabilitas tinggi (Kappa $=0,67-0,73)$ dan validitas sedang $(r=0,48)$. Analisis data penelitian menggunakan analisis statistik deskriptif kuantitatif dengan persentase. Hasil penelitian menunjukan bahwa remaja laki-laki memiliki persentase dengan kategori aktivitas fisik $8 \%$ rendah, $44 \%$ sedang, dan $48 \%$ tinggi. Sedangkan remaja perempuan memiliki persentase dengan kategori aktivitas fisik $8 \%$ rendah, $46 \%$ sedang, dan $46 \%$ tinggi. Data yang diperoleh menunjukkan bahwa sebagian besar aktivitas fisik remaja laki-laki dan perempuan yang mengikuti car free day Dago Kota Bandung mempunyai tingkat aktivitas fisik dalam kategori tinggi.
\end{abstract}

(C) 2018 Universitas Pendidikan Indonesia 


\section{PENDAHULUAN}

Olahraga merupakan suatu kegiatan dimana tubuh kita berperan aktif dan gerak untuk melakukan aktivitas. Oleh karena itu olahraga sangat berpengaruh dalam kehidupan kita (Hasibuan, 2010). Akan tetapi banyak remaja atau masyarakat yang kurang memperhatikan manfaat dari berolahraga, salah satu contohnya terjadi di kawasan car free day Dago Kota Bandung.

Pada masa remaja terjadi perubahanperubahan fisik, baik yang bersifat struktural maupun fungsinya yang berbeda antara remaja laki-laki dan remaja perempuan (Rochaniningsih, 2014). Gejala-gejala perubahan fisik remaja muncul ketika anak mulai memasuki masa awal remaja, dimana perubahan tersebut hampir selalu disertai dengan perubahan sikap dan perilaku. Perubahan tersebut merupakan salah satu dampak dari pengalaman yang belum pernah dirasakannya. Hal ini menyebabkan sering terjadinya permasalahan ataupun ketidakseimbangan pada diri remaja.

Perubahan gaya hidup yang menjurus ke moderenitas dan gaya hidup ala barat sering ditemukan di kota-kota besar di Indonesia. (Satoto, 1994), kemakmuran dan kemudahan hidup, menimbulkan gaya hidup sedentary, yang sangat menurunkan kerja atau aktivitas fisik. Satoto (1994) juga menuturkan bahwa rendahnya aktivitas fisik dalam gaya hidup modern juga disebabkan oleh penafsiran yang salah tentang peranan olahraga yang hanya dibatasi pada kenikmatan (entertainment). Ditambah lagi dengan kecenderungan masyarakat kota saat ini dengan gaya hidup sedentary.

Car free day cukup diminati masyarakat di kota Bandung, contoh nya di Jl. Ir. H. Juanda (Dago), hampir setiap hari minggu banyak masyarakat yang memadati kawasan J1. Dago. Banyak kegiatan olahraga yang dilakukan seperti Senam bersama, jogging, bersepeda, hingga bersepaturoda. Dan juga banyak kegiatan non olahraga yang berjalan, seperti panggung musik, kuis, hingga transaksi jual beli.
Tak pelak kegiatan-kegiatan ini banyak menyedot animo masyarakat untuk tidak hanya diam di rumah pada hari minggu pagi nya. Sehingga banyak faktor yang dapat mempengaruhi masyarakat untuk mendatangi kawasan car free day. Selain karena kawasan car free day terdapat di jalanan utama kota Bandung yang mudah dijangkau, tersedia tempat senam aerobik yang nyaman dan gratis, ataupun bagi komunitas skateboard dan sepatu roda karena kondisi jalanan yang mulus dapat menunjang aktivitas nya.

Sebagai pemanfaatan ruang terbuka di hari libur, program car free day ini cukup efektif digunakan untuk berolahraga, namun perlu di telisik lebih dalam motivasi yang mendasari masyarakat atau remaja untuk mengikuti program car free day. (Riskesdas, 2007) menurut kelompok umur, kurang aktivitas fisik paling tinggi terdapat pada kelompok 75 tahun ke atas $(76,0 \%)$ dan umur 10-14 tahun $(66,9 \%)$, dan perempuan $(54,5 \%)$ lebih tinggi dibanding lakilaki $(41,4 \%)$. Berdasarkan tingkat pendidikan, semakin tinggi pendidikan semakin tinggi prevalensi kurang aktivitas fisik. Prevalensi kurang aktivitas fisik penduduk perkotaan $(57,6 \%)$ lebih tinggi di banding perdesaan $(42,4 \%)$, dan semakin tinggi tingkat pengeluaran per kapita per bulan semakin meningkat prevalensi kurang aktifitas fisik (Delima, Mihardja, \& Siswoyo, 2009). Hal tersebut sesuai dengan surpvey peneliti dimana banyak remaja perempuan yang melakukan aktivitas fisik dibandingkan laki-laki di kawasan car free day Dago Kota Bandung, sehingga peneliti bertujuan untuk menyusun penelitian yang berjudul "Perbedaan Aktivitas Fisik Remaja Laki-Laki dan Perempuan Yang Mengikuti Car Free Day Dago Kota Bandung".

\section{METODE}

Metode yang digunakan pada penelitian ini adalah deskriftip kuantitatif. Desain penelitian dengan paradigma ganda dengan dua variable dependen. Teknik pengambilan sampel yang di gunakan adalah teknik sampel kuota 
sehingga dalam penelitian ini peneliti mendasarkan pada jumlah sampel yang akan di ambil, peneliti menetapkan melakukan pengambilan sampel sebanyak 100 sampel dengan usia rata-rata 19-24 tahun yang terbagi dari 50 sampel remaja laki-laki dan 50 sampel remaja perempuan tanpa menghiraukan asal dari subjek tersebut asalkan masih berada di dalam populasi car free day Dago Kota Bandung. Sehingga pada penelitian ini harus di lakukan hingga kuota yang di tetapkan terpenuhi, (Arikunto, n.d.) yang terpenting di perhatikan di sini adalah terpenuhinya jumlah (quantum) yang telah di tetapkan.

Instrument yang digunakan adalah Global Physical Activity Questionnaire, yaitu merupakan instrumen dalam bentuk kuesioner yang diadopsi dari World Health Organization (Organization, 1975) yang digunakan untuk mengukur tingkat aktivitas fisik masyarakat di seluruh dunia, Dimana QPAQ sudah di standarisasi secara internasional. Banyak penelitian-penelitian sebelumnya yang menggunakan kuesioner ini, termasuk di Negara berkembang (Adhitya, 2016), dan penelitian sebelumnya sudah menguji validitas (Bull, Maslin, \& Armstrong, 2009), Penelitian terdahulu yang dilakukan oleh Bull, Maslin dan Armstrong tahun 2009 di berbagai negara termasuk Indonesia di kota Yogyakarta mengungkapkan bahwa penelitian ini memiliki nilai reliabilitas kuat (Kappa 0,67 sampai 0,73). Sementara itu, berdasarkan penelitian (Cleland et al., 2014) nilai aktivitas fisik dari Global Physical Activity Questionnaire (GPAQ) memiliki tingkat validitas sedang dikorelasikan dengan data dari accelerometer $(r=0.48)$.

Pengukuran tingkat aktivitas fisik didasarkan pada besar MET (Metabolic Equivalent) yang merupakan nilai yang digunakan untuk menentukan tingkat aktivitas fisik berdasarkan Global Physical Activity Questionnaire (GPAQ). Penggunaan kuesioner ini adalah dengan mengisikan pernyataan atas pertanyaan yang disediakan pada kuesioner. Pertanyaan mengarah dalam tiga domain, yaitu kegiatan di tempat kerja (aktivitas termasuk kegiatan belajar, latihan, aktivitas rumahtangga, d1l), perjalanan dari tempat ke tempat (aktivitas termasuk kegiatan perjalanan ke tempat kerja, berbelanja, beribadah, dll), dan kegiatan rekreasi (aktivitas termasuk olahraga, fitness, dan rekreasi lainnya). Responden diminta untuk mengisikan pernyatan mengenai aktivitas yang dilakukan sehari-hari dan juga intensitas waktu yang diperlukan.

Analisis dan pengolahan data pada penelitian ini yaitu mengumpulkan data dari responden dengan memberi kuesioner GPAQ terhadap responden, dalam pengisian kuesioner responden diminta mengisi dengan apa adanya untuk meyakinkan agar data yang didapat objektif, mengumpulkan kuesioner yang sudah diisi oleh responden. Kemudian data di olah melalui bantuan perangkat lunak IMB SPSS versi 22 dan Microsaoft Excel 2013.

\section{HASIL}

Data hasil yang diperoleh dari GPAQ mencakup tiga domain aktivitas yaitu aktivitas pada saat bekerja, perjalanan, dan rekreasi.

Tabel 1. Jumlah Remaja Yang Melakukan Aktivitas Fissik Di Semua Domain

\begin{tabular}{|c|c|c|}
\hline $\begin{array}{c}\text { Jenis } \\
\text { Kelamin }\end{array}$ & $\begin{array}{c}\text { Aktivitas fissik di semua } \\
\text { domain (bekerja, perjalanan, } \\
\text { rekreasi) }\end{array}$ & Presemtase \\
\hline $\begin{array}{c}\text { Remaja } \\
\text { Laki-laki }\end{array}$ & 22 & $55 \%$ \\
\hline $\begin{array}{c}\text { Remaja } \\
\text { Perempuan }\end{array}$ & 18 & $45 \%$ \\
\hline TOTAL & 40 & $100 \%$ \\
\hline
\end{tabular}

Dari data yang diolah dapat diketahui jumlah remaja yang melakukan aktivitas fissik di semua domain (bekerja, perjalanan, rekreasi), terdapat sebanyak 40 Remaja atau 40\% dari semua remaja yang melakukan aktivitas fisik dari semua domain (bekerja, perjalanan, rekreasi), 22 orang atau 55\% diantaranya adalah laki-laki dan 18 orang atau $45 \%$ di antaranya adalah perempuan. 
Tabel 2. Tingkat Aktivitas Fisik Remaja Lakilaki

\begin{tabular}{|c|c|c|}
\hline $\begin{array}{c}\text { Kategori } \\
\text { Aktivitas fisik }\end{array}$ & Frekuensi & Presentase \\
\hline Rendah & 4 & $8 \%$ \\
\hline Sedang & 22 & $44 \%$ \\
\hline Tinggi & 24 & $48 \%$ \\
\hline Total & $\mathbf{5 0}$ & $\mathbf{1 0 0} \%$ \\
\hline
\end{tabular}

Dari tabel 1.2 dapat dilihat bahwa aktivitas fisik remaja laki-laki yang mengikuti car free day Dago Kota Bandung dari data yang diperoleh 4 atau $8 \%$ remaja laki-laki memiliki tingkat aktivitas rendah, 22 atau 44\% memiliki tingkat aktivitas sedang, dan 24 atau $48 \%$ memiliki tingkat aktivitas fisik tinggi.

Tabel 3. Tingkat Aktivitas Fisik Remaja Perempuan

\begin{tabular}{|c|c|c|}
\hline $\begin{array}{c}\text { Kategori Aktivitas } \\
\text { fisik }\end{array}$ & Frekuensi & Presentase \\
\hline Rendah & 4 & $8 \%$ \\
\hline Sedang & 23 & $46 \%$ \\
\hline Tinggi & 23 & $46 \%$ \\
\hline Total & $\mathbf{5 0}$ & $\mathbf{1 0 0} \%$ \\
\hline
\end{tabular}

Dari tabel 1.3 dapat dilihat bahwa aktivitas fisik remaja perempuan yang mengikuti car free day Dago Kota Bandung dari data yang diperoleh 4 atau $8 \%$ remaja perempuan memiliki tingkat aktivitas rendah, 23 atau 46\% memiliki tingkat aktivitas sedang, dan 23 atau $46 \%$ memiliki tingkat aktivitas fisik tinggi.

Tabel 4 Tingkat Aktivitas Fisik Remaja Yang Mengikuti Car Free Day Dago Kota Bandung Secara Keseluruhan Antara Laki-Laki dan Perempuan

\begin{tabular}{|c|c|c|}
\hline $\begin{array}{c}\text { Kategori } \\
\text { Aktivitas fisik }\end{array}$ & Frekuensi & Presentase \\
\hline Rendah & 8 & $8 \%$ \\
\hline Sedang & 45 & $45 \%$ \\
\hline Tinggi & 47 & $47 \%$ \\
\hline Total & $\mathbf{1 0 0}$ & $\mathbf{1 0 0} \%$ \\
\hline
\end{tabular}

Dari tabel 1.4 dapat dilihat bahwa aktivitas fisik remaja laki-laki dan perempuan yang mengikuti car free day Dago Kota Bandung dari data yang diperoleh 8 atau $8 \%$ remaja laki-laki dan perempuan memiliki tingkat aktivitas rendah, 45 atau 45\% memiliki tingkat aktivitas sedang, dan 47 atau $47 \%$ memiliki tingkat aktivitas fisik tinggi.

Penelitian ini bertujuan untuk mengetahui perbedaan aktivitas fisik remaja laki-laki dan perempuan yang mengikuti car free day Dago Kota Bandung. Sebelum memulai uji perbedaan, hal penting yang perlu diperhatikan yaitu melakukan uji normalitas dan uji homogenitas terlebih dahulu sebagai prasyarat. Uji normalitas dan uji homogenitas perlu dilakukan untuk menentukan statistika yang akan digunakan dalam uji perbedaan.

Diketahui bahwa nilai Asymp. Sig untuk aktivitas fisik remaja laki-laki dan perempuan adalah 0,408 .

Tabel 5. Uji beda

Test Statistics ${ }^{\mathrm{a}}$

\begin{tabular}{|c|r|}
\hline & Aktivitas Fisik \\
\hline Mann-Whitney U & 1130.000 \\
Wilcoxon W & 2405.000 \\
Z & -.827 \\
Asymp. Sig. (2-tailed) & .408 \\
\hline
\end{tabular}

a. Grouping Variable: Jenis Kelamin

Diketahui bahwa nilai Asymp. Sig. untuk aktivitas fisik remaja laki-laki dan perempuan adalah 0,408. Karena Asymp (sig.) 0,408 > 0,05 maka H0 Diterima. Artinya tidak terdapat perbedaan yang signifikan antara aktivitas fisik remaja laki-laki dan perempuan yang mengikuti car free day Dago Kota Bandung. Dapat dikatakan bahwa aktivitas fisik remaja laki-laki dan perempuan yang mengikuti car free day Dago Kota Bandung memiliki aktivitas fisik yang sama rata.

Berdasarkan hasil penelitian dan pembahasan, diketahui bahwa sebesar 45\% (45 remaja) mempunyai tingkat aktivitas fisik dalam kategori sedang, sebesar $8 \%$ (8 remaja) dalam 
kategori rendah, dan sebesar $47 \%$ (47 remaja) dalam kategori tinggi. Data yang diperoleh menunjukkan bahwa sebagian besar aktivitas fisik remaja laki-laki dan perempuan yang mengikuti car free day Dago Kota Bandung mempunyai tingkat aktivitas fisik dalam kategori tinggi. Hal tersebut tidak lepas dari banyaknya remaja yang datang ke car free day Dago Kota Bandung adalah masih berstatus pelajar dimana mereka masih mempunyai intensitas aktivitas fisik yang padat baik di sekolah maupun di luar sekolah.

Berdasarkan hasil penelitian dan pembahasan mengenai "perbedaan aktivitas fisik remaja laki-laki dan perempuan yang mengikuti car free day Dago Kota Bandung" Dengan menggunakan teknik statistik non parametrik diketahui bahwa nilai Asymp. Sig. untuk aktivitas fisik remaja laki-laki dan perempuan adalah 0,408. Karena Asymp (sig.) $0,408>0,05$ maka H0 Diterima. Artinya tidak terdapat perbedaan yang signifikan antara aktivitas fisik remaja laki-laki dan perempuan yang mengikuti car free day Dago Kota Bandung. Dapat dikatakan bahwa aktivitas fisik remaja laki-laki dan perempuan yang mengikuti car free day Dago Kota Bandung memiliki aktivitas fisik yang sama rata.

Berdasarkan data hasil penelitian terdapat beragam nilai MET dari remaja yang mengikuti car free day Dago Kota Bandung. Rentang nilai MET yaitu mulai dari nilai terendah yaitu 300 MET menit/minggu atau setara 5 jam sampai nilai tertinggi 6840 MET menit/minggu atau setara $114 \mathrm{jam}$. Dari data yang diperoleh sebanyak 45 atau $45 \%$ remaja mempunyai nilai MET dalam interval $3000>$ MET $\geq 600$ yang menunjukkan dalam kategori tingkat sedang, sebanyak 8 atau $8 \%$ remaja mempunyai nilai MET dalam interval $600<$ MET yang menunjukkan dalam kategori rendah, sebanyak 47 atau $47 \%$ remaja mempunyai nilai MET $\geq 3000$ yang menunjukkan dalam kategori tinggi. Nilai MET dari seluruh remaja mempunyai rata-rata 2886 MET menit/minggu atau setara 48 jam yang berada pada interval $3000>\mathrm{MET} \geq 600$, maka dari hasil tersebut didapatkan bahwa tingkat aktivitas fisik remaja yang mengikuti car free day Dago Kota Bandung sebagian besar termasuk dalam kategori sedang.

\section{KESIMPULAN}

Hasil dari penelitian dapat disimpulkan bahwa, remaja yang terlibat di car free day Dago Kota Bandung memiliki kategori aktivitas fisik sedang hingga tinggi.

\section{DAFTAR PUSTAKA}

Adhitya, S. D. (2016). Tingkat Aktivitas Fisik Operator Layanan Internet Mahasiswa Universitas Negeri Yogyakarta. Fakultas Ilmu Keolahragaan.

Arikunto, S. (n.d.). Suharsimi. 2010. Prosedur Penelitian Suatu Pendekatan Praktik.

Bull, F. C., Maslin, T. S., \& Armstrong, T. (2009). Global physical activity questionnaire (GPAQ): nine country reliability and validity study. Journal of Physical Activity and Health, 6(6), 790-804.

Cleland, C. L., Hunter, R. F., Kee, F., Cupples, M. E., Sallis, J. F., \& Tully, M. A. (2014). Validity of the global physical activity questionnaire (GPAQ) in assessing levels and change in moderate-vigorous physical activity and sedentary behaviour. BMC Public Health, 14(1), 1255.

Delima, D., Mihardja, L., \& Siswoyo, H. (2009). Prevalensi dan faktor determinan penyakit jantung di Indonesia. Buletin Penelitian Kesehatan, 37(3 Sep).

Hasibuan, R. (2010). Terapi sederhana menekan gejala penyakit degeneratif. Jurnal Ilmu Keolahragaan, 8(2), 78-93.

Organization, W. H. (1975). Official records of the World Health Organization. United Nations, World Health Organization, Interim Commission.

Riskesdas. (2007). Laporan Riset Kesehatan Dasar (Riskesdas) 2007 Bidang Biomedis. Jakarta: Badan Litbangkes, Depkes RI.

Rochaniningsih, N. S. (2014). Dampak pergeseran peran dan fungsi keluarga pada perilaku menyimpang remaja. Jurnal Pembangunan Pendidikan: Fondasi Dan Aplikasi, 2(1).

Satoto, S. (1994). Metode Penelitian Sastra II. Surakarta. Univesitas SebelasMaret Press. 